\title{
Who Trusts Berlusconi? An Econometric Analysis of the Role of Television in the Political Arena
}

\author{
Fabio Sabatini*
}

\section{INTRODUCTION}

Silvio Berlusconi has dominated Italian political life since he was first elected prime minister in 1994. He has been the third longest-serving prime minister of Italy, after Benito Mussolini and Giovanni Giolitti, and, as of May 2011, he was the longest-serving current leader of a G8 country. This political longevity is often difficult to understand for foreign political analysts. The former Italian prime minister has an extensive record of criminal allegations, including mafia collusion, false accounting, tax fraud, corruption and bribery of police officers and judges ${ }^{1}$. Recently, he has even been charged with child prostitution. In a famous editorial published in April 2001, the respected British newsmagazine The Economist stated that: "In any self-respecting democracy it would be unthinkable that the man assumed to be on the verge of being elected prime minister would recently have come under investigation for, among other things, money-laundering, complicity in murder, connections with the Mafia, tax evasion

* Email: fabio.sabatini@uniroma1.it. Postal address: Sapienza University of Rome, Faculty of Economics, via del Castro Laurenziano 9, 00161, Roma - Italy. Department of Economics and Law, Sapienza University of Rome. European Research Institute on Cooperative and Social Enterprises (Euricse), Trento. The empirical analysis in this paper is based on data collected within a research project promoted and funded by the European Research Institute on Cooperative and Social Enterprises (Euricse), Trento. The findings, interpretations and conclusions expressed in the paper are solely of the author and do not necessarily represent the views of Euricse. I am deeply indebted to Damiano Fiorillo and Francesca Modena for indispensable suggestions. I am grateful to the editors of Kyklos for helpful remarks, to Carlo Borzaga, whose advice helped to improve the design of the research in a number of ways, and to Beatrice Valline, who provided excellent assistance in the development of the questionnaire. The paper also benefited from comments by Alexander Stille, Michela Giovannini and David Roodman. A special thank goes to Alessandra Gualtieri for precious conversations on my research topics. Needless to say, usual disclaimers apply.

1. The mafia prosecution was dropped due to the expiration of statutory terms for preliminary inquiry (Ginsborg 2005). False accounting prosecution was dropped because of a law passed by Berlusconi's parliamentary majority that made false accounting illegal only if a specific damaged party reports the fact to the authorities (Blondel and Segatti 2003). For bribery of judges and tax evasion, charges were dropped because the statute of limitations had expired (Warner 2007). Trials for bribery, corruption and child prostitution are currently in progress (Center for the Study of Democracy 2010). 
and the bribing of politicians, judges and the tax police"2. According to The Economist, one of the main explanations of Mr Berlusconi's political success is his exceptional grip on Italy's media. “Through his Mediaset empire, he controls most of Italian private television. As prime minister, he indirectly controls Italian public service television (Radio Televisione Italiana, RAI), giving him influence over some $90 \%$ of Italian TV"3. The media power that Berlusconi has built his empire on is indeed unimaginable in any other western democracy ${ }^{4}$.

Not surprisingly, rightist opinion leaders argue that television does not influence political opinion. This view is widespread in the Italian political debate and leads commentators to affirm that, even if Italians are well aware of Mr Berlusconi's criminal allegations as well as of his personal and political limitations, they actually trust the former prime minister because they feel a deep affinity with him. This argument implies that Mr Berlusconi's political success is not specifically related to the power of his media empire to bias public opinion. If the assumption of television's irrelevance was true, one could reasonably expect to find no significant individual-level relationship between trust in television and trust in Mr Berlusconi.

So far it has been impossible to carry out an econometric test of this thesis. The most comprehensive Italian surveys are conducted by public institutions, such as the National Bureau of Statistics and the Bank of Italy, which cannot collect information on interviewees' political preferences. On the other hand, political opinion polls carried out by private agencies cannot administer excessively long questionnaires able to collect comprehensive data on the social and economic background of respondents.

In this paper, we use a unique dataset to carry out the first econometric investigation into the relationship between trust in television and trust in $\mathrm{Mr}$ Berlusconi as the Italian prime minister. Raw data were collected through the administration of a questionnaire to a representative sample $(n=817)$ of the population of the Italian Province of Trento in March 2011, when Mr Berlusconi

2. The Economist, "An Italian story", published in the issue of April 28th 2001. This issue had the cover title: "Why Silvio Berlusconi is unfit to lead Italy" and provoked a heated debate in Italy. In July 2001 Mr Berlusconi launched a lawsuit in Italy alleging that The Economist had defamed him in the article. The court in Milan has issued a judgment rejecting all of Mr Berlusconi's claims and requiring him to make a payment for costs to The Economist. Mr Berlusconi's lawyers have announced that he will appeal.

3. The Economist, "Mamma mia. Italians may come to regret electing Silvio Berlusconi once again", published on April 17th 2008.

4. It must be remembered that RAI has never been an independent public service broadcaster, since it has always been subject to the distribution of posts and power according to political affiliation. As head of the government, Berlusconi had de facto power to appoint the managers of RAI and the directors of the majority of RAI's information and entertainment broadcasts. RAI channels have traditionally been divided along political lines. RAI 1 and $R A I$ 2are relatively centre right and currently give manifest support to Mr Berlusconi's political action. RAI 3, the most independent channel of the public broadcasting system (PBS), is commonly viewed as the opposition channel (Brevini 2010). 
was firmly in charge as prime minister. The sample was stratified by age, gender and area of residence. The questionnaire was specifically designed for the evaluation of individuals' values, beliefs and behaviours, along with a wide range of relevant socio-demographic and economic characteristics ${ }^{5}$.

Our dependent variable is measured through the question: "Do you think that the prime minister can be trusted?". Interviewees were asked to give a score from 1 to 10 for their trust, 1 meaning "Not at all" and 10 meaning "Totally". The main independent variable is trust in television, as measured by the score from 1 to 10 given by respondents to the question: "Do you think that television can be trusted?".

Probit and ordered logit estimates clearly show that trust in television was the most significant predictor of trust in the prime minister and that this finding is robust to different specifications. However, there are three reasons for which this result could be interpreted as the fruit of a spurious correlation. First, it is difficult to distinguish the effect of trust in television from that of other phenomena that potentially influence trust in the prime minister. To deal with this problem, we include in the trust equation a wide set of individual and household control variables. We place a special focus on the possible role of social capital, which is traditionally claimed to play a role in making democracy work at the community level. Specifically, we account for multiple indicators of both structural and cognitive dimensions of social capital. Second, individual effects, such as individuals' exogenous shocks, may be correlated with trust both towards television and the prime minister, thus creating a common bias. Third, it is reasonable to assume the existence of reverse causality: Mr Berlusconi's television empire has helped shape the country's imagination over a generation, and he invites citizens to trust his media. To deal with the last two problems, we turn to instrumental variables (IV) estimates.

When we address endogeneity in IV estimates, trust in television remains the best (most significant and strongest) predictor of trust in the prime minister. Interestingly, trust in the press is not an explanatory variable. Social capital variables are also found to be irrelevant. Certain categories of self-employed workers - i.e. farmers and members of professions - are found to be more likely to trust the prime minister. By contrast, we find that the dependent variable is significantly and negatively correlated with trust in the judicial system and with a measure of tolerance towards immigrants.

Even if these results pass robustness checks and hold in IV estimates, it must be remarked that the cross-sectional design of the research dictates extreme caution in the interpretation of correlations as causal relationships. Nonetheless,

5. The questionnaire was administered through computer assisted telephone interviewing by the Technical Unit of the Department of Sociology and Social Research of the University of Trento. I thank Cristiano Santinello and Paola Capuana for useful comments to previous versions of the questionnaire. 
the paper contributes to the literature by carrying out the first econometric investigation into the role of television in individuals' political opinions, with a focus on trust towards the Italian prime minister. The relationship between television and political attitudes and beliefs is an important topic for economics, in view of the unquestionable role that political institutions, particularly the government and the prime minister, play in a country's economic performance (Besley and Burgess 2002; Connolly and Hargreaves Heap 2007). However, this topic is largely neglected in the literature. This paper aims to take a step in filling that gap. The use of a unique and very recent (March 2011) dataset collected in a region traditionally characterized by efficient public institutions and very contained inequalities adds further value to the analysis.

The remainder of the paper is organized as follows. The next section describes the data and our empirical strategy. Section 3 presents and discusses the results of the estimates. Concluding remarks and a brief discussion of policy implications close the paper.

\section{DATA AND EMPIRICAL STRATEGY}

Our dependent variable is given by responses to the question: "Do you think that the prime minister can be trusted?". Interviewees were asked to give a score from 1 to 10 for their trust, 1 meaning "Not at all" and 10 meaning "Totally". We followed the approach to code 1 for responses above 6. Still, all results presented in this paper are robust to a different specification of the dependent variable in which responses above the mean value are coded 1. It must be stated that interviewers did not explicitly mention the name of Silvio Berlusconi. So, it is theoretically possible that some respondents' answers referred to the institution of the presidency of the council of ministers, rather than to the person of the prime minister. However, the questionnaire was administered in March 2011, when the man and his institutional office were virtually indistinguishable. In our view, in the context of the contemporary Italian political arena, the assumption that the above-mentioned responses can be used to score citizens' trust towards $\mathrm{Mr}$ Berlusconi is reasonably reliable.

Trust in television is measured by the score from 1 to 10 given by respondents to the question: "Do you think that television can be trusted?", 1 meaning "Not at all" and 10 meaning "Totally". We followed the approach to code 1 for responses above the mean value. Results are robust to a different specification of the independent variable where responses above 6 are coded 1 .

Our choice to focus on the Province of Trento was due to results from recent empirical studies which found the territory to be characterized by contained inequalities, efficient public institutions, and above average levels of material and subjective well-being (Degli Antoni 2006, 2009; Fiorillo 2008; Sabatini 2008, 2009a). Administratively, the Province enjoys a large degree of autonomy 
in the following sectors: health, education, welfare and transport infrastructure. In our view, these characteristics do not imply a particular bias in terms of political opinions. More in particular, we argue it is not possible to establish whether the traditionally well-known efficiency of local public institutions could reinforce trust towards the Italian prime minister as an institution in himself, since the Province has been governed by centrist or centre-leftist coalitions for a long time. Overall, results from past elections suggest that political opinions of the Trentino Region' $s^{6}$ population seem not to be particularly biased in favour $\mathrm{Mr}$ Berlusconi's party (see Table A2 in the Appendix).

\section{Probit estimates}

In Model 1 we control for a number of socio-demographic and economic characteristics (see column 1 in Table 2). At the household level, the analysis accounts for a measure of economic well-being given by responses to the question: "Is your household's income sufficient to see you through to the end of the month?". Respondents were asked to give a score from 1 to 5 , with 1 meaning "With great difficulty" and 5 meaning "Very easily". We coded 1 for negative responses (i.e. "With great difficulty" and "With difficulty") and used the label "Poor" to indicate the dichotomous variable in regressions. Robustness checks were performed by replacing this measure with two other indicators of economic well-being. The first is given by responses to the question: "How would you place your household income in respect to the average income of Italian households?". Respondents were asked to give a score from 1 to 5, 1 meaning "Much below the average" and 5 meaning "Much above the average". The second measure of economic well-being used in robustness checks is given by responses to the question: "Overall, how satisfied are you with your economic situation?". Once again, interviewees were asked to give a score from 1 to 10 , with 1 meaning "Not at all" and 10 meaning "Totally satisfied".

At the individual level, the analysis accounts for the following control variables:

- Education, treated as an ordinal variable where each category corresponds to a degree of educational qualification. Results do not change if we include dummy variables corresponding to each level of qualification.

- Work status, as indicated by a number of dummies reporting whether the interviewee is a blue-collar worker, office worker, teacher, managerial employee, member of profession, entrepreneur, farmer, pensioner, homemaker, or unemployed. Students are the omitted category in regressions.

6. Hereafter we will use "Province of Trento" and "Trentino Region" as synonyms. 
Table 1

Summary statistics

\begin{tabular}{lcc}
\hline & Mean & St. deviation \\
\hline Trust in the Italian prime minister & 0.23 & 0.42 \\
Trust in television & 0.59 & 0.49 \\
Membership of associations & 0.32 & 0.47 \\
Number of associations & 0.54 & 0.96 \\
Volunteer unpaid work for associations & 0.27 & 0.44 \\
Help to strangers within volunteering activities & 0.21 & 0.40 \\
Participation in associational meetings & 0.29 & 0.45 \\
Social trust & 0.42 & 0.49 \\
Trust in the judicial system & 0.62 & 0.48 \\
Tolerance towards non EU immigrants & 0.74 & 0.44 \\
Tolerance towards EU immigrants & 0.86 & 0.35 \\
Tolerance towards drug or alcohol addicts & 0.44 & 0.50 \\
Age 35-49 & 0.29 & 0.46 \\
Age 50-64 & 0.23 & 0.42 \\
Age 65 and more & 0.24 & 0.42 \\
Female & 0.52 & 0.50 \\
Being in a stable relationship & 0.72 & 0.45 \\
Educational qualification (ordinal) & 4.45 & 1.48 \\
Precarious worker & 0.01 & 0.10 \\
Blue-collar worker & 0.12 & 0.33 \\
Office worker & 0.23 & 0.42 \\
Teacher & 0.04 & 0.20 \\
Managerial employee & 0.02 & 0.13 \\
Member of professions & 0.04 & 0.20 \\
Entrepreneur & 0.01 & 0.12 \\
Farmer & 0.04 & 0.20 \\
Unemployed & 0.02 & 0.16 \\
Retired & 0.26 & 0.44 \\
Homemaker & 0.08 & 0.28 \\
Area or residence (urban vs. rural) & 0.36 & 0.48 \\
Poor & 0.15 & 0.36 \\
\hline
\end{tabular}

Observations for the variable "Trust in the Italian prime minister" $=754$. Observations for all the other variables $=817$

- Usual socio-demographic controls such as gender, being in a stable relationship, age, and the area of residence (urban vs. rural).

All the variables are described in detail in Table A1 in Appendix A. Summary statistics are reported in Table 1.

The measurement of social capital is a delicate and controversial issue which we prefer not to discuss here. For a comprehensive survey of methodological problems in the empirical literature on social capital, we refer the reader to the reviews in Fine (2001, chapter 10), Durlauf and Fafchamps (2005) and Sabatini (2007, 2009a). In model 2, we account for the "structural" dimensions of the concept. The structural dimension deals with individuals' behaviours and can take the form of relational goods consumption, participation in social networks, 
and volunteering activities. Cognitive social capital deals with agents' perceptions and involves concepts such as trust, reciprocity, and shared beliefs (Uphoff 1999).

In this paper, we measure structural social capital through membership of voluntary organizations, as given by a number of indicators capturing:

- the number of associations in which the interviewee participates, both through a formal membership or through informal participatory activities.

- The type of association, as measured by a number of dummy variables. In particular, the analysis includes cultural, recreational, health and assistance, advocacy, environmental and religious associations.

- Attendance at associational meetings, measured through a binary variable coded 1 if the respondent had joined meetings in the last 12 months before the interview.

- Volunteering, measured through a binary variable coded 1 if the respondent had done unpaid volunteer work in the last 12 months before the interview.

- Altruism, measured through a binary variable coded 1 if the respondent had concretely helped strangers within her volunteering activities in the last 12 months before the interview.

In model 3 we add measures of cognitive social capital, as given by two indicators of social trust and trust towards the institutions, and three indicators of "tolerance". Social trust was measured through the standard trust question, "In general, do you think most people can be trusted or can't you be too careful?" introduced to large U.S. surveys by Rosenberg (1956). Institutional trust is measured through the scores from 1 to 10 given by responses to the question "Do you feel that the judicial system can be trusted?", with 1 meaning "Not at all" and 10 meaning "Totally". In both cases responses were recoded 1 if their value was above the mean.

In principle, it could be argued that at the community level a vibrant social environment which allows people to meet frequently and to share information, opinions and experience might scale down the role of mass media in the formation of political preferences. Indeed it seems somewhat significant that the Province of Trento, which according to previous studies enjoys an exceptional wealth of community social capital (Sabatini 2008, 2009b), has always exhibited a relatively moderate consensus for the prime minister's party. However, as column 2 of Table 2 reports, most social capital variables are found to be irrelevant at the individual level.

Tolerance was measured through the question: "Which of these categories of people would you be willing to have as neighbours", where categories were non EU immigrants, EU immigrants, alcohol or drug addicts, and people who declare themselves to be racist. 


\section{Instrumental variables estimates}

As will be reported in section 3, probit estimates clearly show that trust in television is the most significant predictor of trust in the prime minister, and that this result is robust to different specifications. However, as we mentioned in the introduction, individual effects or other unknown phenomena which we may not be able to account for within the model could be correlated with both the dependent variable and the main regressor, thus creating a common bias. Moreover, there are reasons to suspect the existence of reverse causality: Mr Berlusconi owns or controls the majority of the Italian broadcasting system, so it is reasonable to argue that trusting Mr Berlusconi may also lead citizens to trust his television channels. After a simple regression-based test of endogeneity, we deal with this issue by means of instrumental variables (IV) estimates, as recently seen in d'Hombres et al. (2010) and Yamamura (2011).

In IV estimates, we use two individual-level instruments for trust in television given by the quality of friendships and trust in the press. As the tests reported in section 3 show, these variables satisfy the two necessary conditions for instrument validity, since they are both strongly correlated with trust in television ("relevance" condition) and they are both orthogonal to the disturbance term of the trust in the prime minister equation ("orthogonality" condition).

The quality of friendships is measured through individuals' reported satisfaction with relationships with friends, as given by responses to the question: "How satisfied do you feel with your relationships with friends?".

The relationship between television, relational goods and life satisfaction has already been analyzed in the literature (Putnam 1995; Corneo 2005; Bruni and Stanca 2006, 2008; Frey et al. 2007). Drawing on data from the first wave of the European Social Survey, Frey et al. (2007) find that watching TV is positively related to people's material aspirations and negatively related to their trust in others as well as to relative frequency of social activities. Bruni and Stanca (2006, 2008) use data from the World Values Survey to show that television viewing plays a key role in reducing happiness through two main mechanisms. First, it crowds-out relationality (Bruni and Stanca 2008). Second, it contributes to raising individual material aspirations, thus lowering the effect of higher income on happiness (Bruni and Stanca 2006). Antoci, Sabatini and Sodini (2011a, 2011b) show that under certain conditions the crowding out hypothesis can be generalized to various kinds of technology-intensive consumption, with an exception made for the Internet.

It must be stated that, in respect to the above mentioned literature, in this paper we measure trust in television instead of viewing TV. This difference is critical to the purpose of our study for two main reasons. First, as stated by Frey et al. (2007), subjective time use data may be inaccurate or biased: "Watching television might not be understood in the same way by all respondents, and they might 
not differentiate between television viewing as primary, secondary or even tertiary activity. Respondents might not even correctly remember all the times they were watching television" (p. 290). Moreover, people may watch television without trusting the reliability of its contents. For example, spectators of reality shows are often aware that characters are actually following a script, but they are likely to enjoy the show even if they do not trust its "reality" at all.

Moreover, we refer to relational goods in terms of their quality, rather than to the mere frequency of their consumption. Friendship is a qualitative concept which cannot be measured just through the frequency of meetings with friends. Following Diener and Seligman (2002), in this paper we use satisfaction with relationships with friends as a proxy for the "quality" of friendship. The quality of relationships with friends has been found to be strongly associated with aspects of well-being such as happiness (Baldassarre et al. 1984; Myers 2000; Argyle 2001; Diener and Seligman 2002; Lyubomirsky et al. 2006; Demir and Weitenkamp 2007; Van Praag and Ferrer-i-Carbonell 2008) and health (Fiorillo and Sabatini 2011). Drawing on a sample of 222 undergraduate students, Diener and Seligman (2002) find that the subjective rating of relationships with close friends is the best predictor of happiness. Demir et al. (2007) use a sample of 280 college students to analyze the role of best and close friendships in happiness. The authors find that best friendship quality - as measured by the subjective rating of respondents' relationships with their best friends - is the only significant predictor of happiness.

In the population object of our investigation, the frequency of contact with friends exhibits a weak and positive correlation with trust in television ${ }^{7}$. By contrast, the quality of friendships is found to be significantly and negatively correlated with trust in TV by probit and first stage IV estimates. Arguably, satisfactory relationships which entail mutual trust as well as the exchange of ideas and information may reduce the role of television in the obtaining of social and political information, thereby preventing individuals from uncritically evaluating broadcasting contents. The significance of the correlation, along with the tests of the joint significance of coefficients carried out in section 3 (see Tables 3 and 4), support the assumption that this variable is a relevant instrument.

As for the orthogonality condition, it must be stated that several studies find the quality of friendships to be correlated with certain domains of trust, such as social trust. However, the latter concept is extremely different from the dependent variable we use in the empirical analysis. In support of the hypothesis of orthogonality, probit and ordered logit regressions do not find any significant correlation between the quality of friendships and trust in the former Italian prime minister.

7. Estimates are available upon request to the author. 
The other instrument we use in the analysis, i.e. trust in the press, may be subject to greater contention. One could argue that people who trust the press are not likely to behave and think so differently from those who trust television. Indeed we find the two variables to be significantly correlated in our sample through probit estimates and first stage IV estimates ( $p$ value $=0.000$ ). The test of the joint significance of coefficients (see Tables 3 and 4) also supports the assumption that this variable satisfies the relevance condition. However, this correlation does not imply that trust in television and trust in the press are able to bias political opinions to the same extent and in the same direction.

There are at least three reasons to suspect that the orthogonality condition might be satisfied. First, television and the press are very different media. As stated by Frey et al. (2007), "TV viewing is characterized by immediate benefits and negligible immediate marginal costs. One just has to push a button" (p. 287, italic is ours). By contrast, reading the press requires an active and mindful choice of newspaper, as well as the act of going to a kiosk and paying for the purchase. Compared to reading newspapers, watching TV has virtually no entry barriers, especially in the case of television channels owned or controlled by $\mathrm{Mr}$ Berlusconi (Mediaset and public service channels can be viewed free of charge). Moreover, as reported by Frey et al. (2007), there is anecdotal evidence that individuals may have self-control problems in watching television: it is hardly arguable that the activity of reading newspapers can cause similar problems.

Second, newspaper readers are far fewer in number than TV viewers (Istat 2008). Thus, people who report that they trust the press are not necessarily habitual readers. By contrast, people who trust TV are more likely to be habitual watchers. Overall, in Italy the press is a less influential and pervasive media than the television.

Third, the Italian press is much more pluralist than Italian television. $\mathrm{Mr}$ Berlusconi's family directly owns "only" a small number of newspapers and several magazines, not the majority ${ }^{8}$. Overall, it is possible to state that Italian newspapers more or less equally represent all political views. Thus, trust in the press cannot be correlated with a definite bias in terms of trust or distrust towards the former prime minister. Moreover, local newspapers published in the Province

8. Berlusconi owns Arnoldo Mondadori Editore, the largest Italian publishing house which owns over 50 magazines, including Panorama, one of the country's most popular news magazines, and Chi, and TV Sorrisi e Canzoni, two of the most popular tabloids. His brother, Paolo Berlusconi, owns and operates il Giornale, a right wing newspaper which provides a strong pro-Berlusconi slant on Italy and its politics. Il Foglio, one of the most influential Italian right-wing newspapers, is partially owned by his former wife, Veronica Lario. As for television, the former Italian prime minister owns three of the seven national terrestrial televisions, i.e. Canale Cinque, Italia Uno and Rete Quattro, he holds a minority stake in La 7 and, as head of the government, he has de facto power to control the three country's public television channels, i.e. Rai 1, Rai 2 and Rai 3. Overall, he is in a position to influence more than $90 \%$ of the country's television output. 
of Trento are traditionally moderate and try to remain equidistant from political alignments.

In light of the arguments discussed above and of the estimates carried out within the empirical analysis, it seems reasonable to assume that, in the population under investigation, there is no direct link between trust in the press and trust in the prime minister. Moreover, as mentioned earlier, we test the validity of our instruments with over-identification tests presented in Tables 3 and 4.

\section{EMPIRICAL RESULTS}

Our empirical model of trust in the former Italian prime minister can be represented through the following estimation equation:

$$
\text { trust in } S B_{i t}^{*}=\alpha+\text { trust in } T V_{i t} \beta+\text { social capital }{ }_{i t}^{\prime} \gamma+Z_{i t}^{\prime} \delta+\varepsilon_{i t}
$$

where the dependent variable is trust in the prime minister for individual $i$ at time $t$, social capital is a vector of indicators of structural and cognitive dimensions of the concept defined at the individual level, the $Z$ vector consists of the other variables that may influence trust in the prime minister, and $\boldsymbol{\epsilon}$ is a random-error term.

We do not observe the "latent" variable trust in $S B_{i t}^{*}$ in the data. Rather, we observe it as a binary variable which takes the value 1 if trust in $S B_{i t}^{*}$ takes values over 6 and 0 otherwise. Thus, the structure of (1) makes it suitable for estimation as a probit model:

$$
\operatorname{Pr}\left(\text { trust in } S B_{i t}=1\right)=\Phi\left(\alpha-\text { trust in } T V_{i t} \beta-\text { social capital }{ }_{i t}^{\prime} \gamma-Z_{i t}^{\prime} \delta\right)
$$

where $\Phi(\cdot)$ is the cumulative distribution function of a normal standard.

Table 2 presents the results of the probit estimates. To compare relative magnitudes of the effects of the independent variables, we report their marginal effects. In model 1 (column 1 of Table 2), we principally focus on trust in television and on a number of covariates representing individual sociodemographic and economic characteristics. Trust in television is found to be the strongest predictor of trust in the prime minister. More precisely, people reporting an above the mean trust in television exhibit a 12 percentage point higher likelihood of also trusting Mr Berlusconi. Trust in the prime minister is significantly and negatively correlated with education.

When education is measured as an ordinal variable, the size effect of each category is significantly lower than that of trust in TV. On the other hand, if we replace the ordinal variable with a number of dummies representing each type of qualification provided by the Italian education system, the significance, sign and 
FABIO SABATINI

Table 2

Probit estimates

\begin{tabular}{|c|c|c|c|c|c|c|}
\hline & \multicolumn{2}{|c|}{ Model 1} & \multicolumn{2}{|c|}{ Model 2} & \multicolumn{2}{|c|}{ Model 3} \\
\hline & $\begin{array}{c}\text { Marginal } \\
\text { effect }\end{array}$ & t stat. & $\begin{array}{c}\text { Marginal } \\
\text { effect }\end{array}$ & t stat. & $\begin{array}{l}\text { Marginal } \\
\text { effect. }\end{array}$ & t stat. \\
\hline Trust in television & 0.12 & 4.19 & 0.12 & 4.17 & 0.16 & 5.44 \\
\hline \multicolumn{7}{|l|}{ Structural social capital } \\
\hline Membership of associations & & & -0.02 & -0.15 & 0.01 & 0.05 \\
\hline Number of associations & & & -0.01 & -0.26 & -0.01 & -0.43 \\
\hline Volunteer unpaid work for associations & & & 0.08 & 0.79 & 0.07 & 0.73 \\
\hline $\begin{array}{l}\text { Help to strangers within volunteering } \\
\text { activities }\end{array}$ & & & -0.04 & -0.64 & -0.01 & -0.25 \\
\hline Participation in associational meetings & & & -0.01 & -0.11 & -0.02 & -0.17 \\
\hline \multicolumn{7}{|l|}{ Cognitive social capital } \\
\hline Social trust & & & & & 0.02 & 0.64 \\
\hline Trust in the judicial system & & & & & -0.07 & -1.88 \\
\hline Tolerance towards non EU immigrants & & & & & -0.08 & -1.63 \\
\hline Tolerance towards EU immigrants & & & & & -1.08 & -1.56 \\
\hline Tolerance towards drug or alcohol addicts & & & & & -0.02 & -0.60 \\
\hline \multicolumn{7}{|c|}{ Demographic, social and economic characteristics } \\
\hline Age $35-49$ & -0.00 & -0.04 & -0.00 & -0.01 & 0.01 & 0.18 \\
\hline Age 50-64 & -0.06 & -1.16 & -0.06 & -1.13 & -0.03 & -0.59 \\
\hline Age 65 and more & -0.09 & -1.54 & -0.09 & -1.52 & -0.08 & -1.26 \\
\hline Female & -0.04 & -1.24 & -0.04 & -1.24 & -0.02 & -0.70 \\
\hline Being in a stable relationship & -0.03 & -0.81 & -0.03 & -0.83 & -0.03 & -0.83 \\
\hline Educational qualification (ordinal) & -0.05 & -5.84 & -0.05 & -5.72 & -0.03 & -3.00 \\
\hline Precarious worker & 0.03 & 0.18 & 0.03 & 0.19 & 0.09 & 0.48 \\
\hline Blue-collar worker & -0.03 & -0.47 & -0.03 & -0.43 & -0.02 & -0.33 \\
\hline Office worker & -0.06 & -1.05 & -0.06 & -1.00 & -0.05 & -0.80 \\
\hline Teacher & -0.03 & -0.26 & -0.02 & -0.21 & -0.04 & -0.42 \\
\hline Managerial employee & 0.19 & 1.20 & 0.18 & 1.16 & 0.19 & 1.18 \\
\hline Member of professions & 0.21 & 1.77 & 0.22 & 1.81 & 0.25 & 2.03 \\
\hline Entrepreneur & 0.03 & 0.19 & 0.02 & 0.12 & 0.06 & 0.33 \\
\hline Farmer & 0.21 & 1.76 & 0.22 & 1.82 & 0.23 & 1.89 \\
\hline Unemployed & -0.04 & -0.41 & -0.04 & -0.40 & -0.04 & -0.45 \\
\hline Retired & 0.08 & 0.96 & 0.08 & 0.97 & 0.10 & 1.18 \\
\hline Homemaker & 0.02 & 0.21 & 0.02 & 0.26 & 0.04 & 0.41 \\
\hline Area or residence (urban vs. rural) & -0.05 & -1.64 & -0.05 & -1.62 & -0.04 & -1.21 \\
\hline Poor & 0.06 & 1.19 & 0.05 & 1.13 & 0.05 & 1.03 \\
\hline
\end{tabular}

Omitted categories are: "Age 18-34" and "Students".

size of the role of TV do not change, and we observe slight changes in the size effect across the different qualifications ${ }^{9}$.

These results are robust to the inclusion of a number of control variables. The more we add covariates to the model, the more the role of trust in television grows in significance and size.

In models 2 and 3 we add indicators of structural and cognitive social capital. Trust in TV is confirmed as the most significant regressor, with a size effect

9. We do not report estimates including all educational qualification dummies in order not to overload tables. Estimates are available upon request to the author. 
increasing to about $15 \%$. Social capital variables seem to be irrelevant, with the exception of the indicator of trust towards the judicial system, which is found to be significantly and negatively correlated with trust towards the prime minister. This is not surprising, since Mr Berlusconi always claims to be the victim of a manifest judicial persecution. He frequently refers to the judicial system as a cancer - and to single judges as "metastases" - in public discourses. People who report an above the mean level of trust in judicial system exhibit an approximately $10 \%$ lower likelihood of trusting the prime minister. Results are robust to the consideration of different types of associations, which are all found to be irrelevant in respect to the dependent variable. As for work status, members of professions and farmers are significantly more likely to trust the prime minister.

Another interesting finding is the significant and negative correlation of tolerance towards immigrants with our dependent variable. The significance and size of trust in television further grows in model 3, the marginal effect now reaching more than $16 \%$. All the other effects remain substantially unchanged.

\section{Endogeneity issues}

As pointed out in section 2, there are two main reasons to suspect the existence of endogeneity problems. First, trust in the prime minister and trust in television are individual choices, which depend on individual specific and unobservable preferences. Hence, they are by definition endogenously determined. Unobservable individual effects such as time preferences, personal interests, and individuals' exogenous shocks may be correlated both with trust in the prime minister and trust in TV. Second, there is concern about possible reverse causality: $\mathrm{Mr}$ Berlusconi hopes his citizens trust his television channels and continuously invites them to do so. Thus, it is likely that people can trust television as a consequence of their trust towards the prime minister.

First, we perform a regression-based test to check whether trust in television is endogenous. If the test fails to reject absence of endogeneity, we can go back and use the probit model (2) to estimate the effect of trust in TV. Otherwise, we are prompted to address endogeneity through IV estimates.

To derive the regression-based test, a two stage procedure is used. The firststage reduced form regression has trust in television as dependent variable and all the exogenous variables as regressors (i.e. the instrumental variables and all exogenous variables included in model 2). As explained in section 2 , the instruments for trust in television are the quality of friendships and trust in the press. At the second-stage, we regress trust in the prime minister on the predicted OLS residuals from the first-stage, on the potential endogenous variable (trust in television), and on all the exogenous variables. A standard t test on the predicted residuals is our test for endogeneity. The test cannot reject the presence of 
Table 3

IV estimates with dichotomous endogenous variable

\begin{tabular}{|c|c|c|c|c|c|c|}
\hline & \multicolumn{2}{|l|}{ Probit } & \multicolumn{2}{|l|}{ OLS } & \multicolumn{2}{|l|}{ GMM } \\
\hline & Marginal effect & t stat. & Marginal effect & t stat. & Marginal effect. & t stat. \\
\hline Trust in television & 0.19 & 3.39 & 0.18 & 2.95 & 0.19 & 3.07 \\
\hline \multicolumn{7}{|c|}{ Instrumental variables diagnostics } \\
\hline & \multicolumn{2}{|c|}{$\begin{array}{l}\text { Amemiya-Lee-Newey } \\
\text { test }\end{array}$} & \multicolumn{2}{|l|}{ Sargan test } & \multicolumn{2}{|l|}{ Hansen test } \\
\hline \multirow{2}{*}{$\begin{array}{l}\text { Test of over-identifying } \\
\text { restrictions: Statistic } \\
(p \text {-value) }\end{array}$} & \multicolumn{2}{|c|}{$\begin{array}{c}\text { chi-sq }(1)=0.094 \\
(0.760)\end{array}$} & \multirow{2}{*}{\multicolumn{2}{|c|}{$\begin{array}{c}\text { chi-sq }(1)=0.114 \\
(0.7352) \\
\text { Basmann test } \\
\text { chi-sq }(1)=0.108 \\
(0.742)\end{array}$}} & \multirow{2}{*}{\multicolumn{2}{|c|}{$\begin{array}{c}\text { chi-sq }(1)=0.112 \\
(0.738)\end{array}$}} \\
\hline & & & & & & \\
\hline $\begin{array}{l}\text { Joint significance } \\
\text { coefficient }\end{array}$ & \multicolumn{2}{|c|}{ chi-sq $(1)=189.87$} & \multicolumn{2}{|c|}{$\mathrm{F}=140.30$} & \multicolumn{2}{|l|}{$F=138.77$} \\
\hline
\end{tabular}

endogeneity $(t=17.61, P>|t|=0.000)$, hence we address endogeneity through instrumental variables (IV) estimates ${ }^{10}$.

Table 3 reports the marginal effects of trust in television in the second stage of the IV estimates, along with diagnostic tests of the validity of our instrumental variable estimators. In column 1 we report results of IV probit estimates. The Amemiya-Lee-Newey test of over-identifying restrictions does not lead us to reject the orthogonality of our instruments with respect to the disturbance term of the trust equation with a $p$-value greater than 0.75 .

As robustness checks, in columns 2 and 3 we report the results of OLS and GMM estimates. The Sargan test and the Basmann test of over-identifying restrictions reported in column 2 do not lead us to reject the null hypothesis that the excluded instruments are valid instruments, i.e., uncorrelated with the error term, and that they are correctly excluded from the estimated equation, with a $p$-value $\cong 0.74$.

In column 3, we report the Hansen-Sargan test of over-identifying restrictions ${ }^{11}$. Once again, the test does not lead us to reject the null with a $p$-value $\cong 0.74$.

In columns 2 and 3, the F-statistics, testing the hypothesis that the coefficient of the excluded instruments are all zero in each first-stage estimate, are well above the threshold of 10 suggested by the literature as the rule of thumb criterion of instrument weakness. Taken together with the non-rejection of the tests of over-identification, this suggests that our set of instruments is reasonable.

Overall, when we address the endogeneity of trust in television in IV estimates, we find a slight increase in its marginal effect, which now grows to about

10. Estimates are available upon request to the author.

11. For the 2SLS estimator, the test statistic is Sargan's statistic. Under the assumption of conditional homoskedasticity, Hansen's J statistic becomes Sargan's statistic. The J statistic is consistent in the presence of heteroskedasticity; Sargan's statistic is not (Baum et al. 2007; Wooldridge 2002). 
Table 4

IV estimates with ordinal endogenous variable

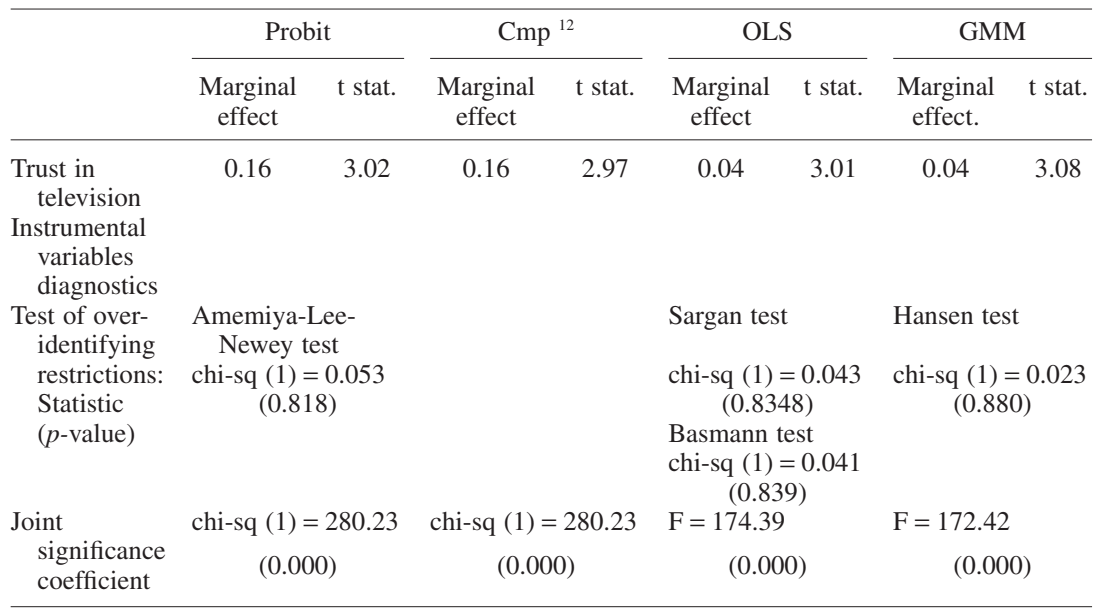

17-18\%. Trust in TV remains the best predictor of trust in the prime minister. Its significance, sign and size remain unchanged in the three models.

In summary, the instrumental variable results confirm the role of trust in television as presented in Table 2.

As a further robustness check, we report in Table 4 results of IV estimates that treat the endogenous variable as an ordinal, i.e. measured on the original 10 points-scale. The upper part of the table contains the marginal effects of trust in television on trust in the prime minister. In addition to estimates shown in Table 3, the second Column reports results of IV estimates calculated through Roodman's (2009) Stata module to implement conditional mixed process (cmp) estimator. As expected, there is a decrease in the marginal effect. The lower part of Table 4 reports the same diagnostic tests described with reference to Table 3.

\section{CONCLUSIONS}

Empirical studies in social psychology have provided some evidence that people vote for politicians whose traits they rate as being most similar to their own (Caprara et al. 2002; Caprara et al. 2007). This view is often invoked with reference to the Italian political debate, where commentators claim that the main

12. Currently there is no Stata code for performing the test of over-identifying restriction after conditional mixed process estimation. However, it can be shown that the excluded variables are not significant in the second stage of the probit estimation. This results supports the Amemiya-Lee-Newey test shown in the first column in suggesting that the instruments can be correctly excluded from the structural equation. Estimates are available upon request to the author. 
reason of Mr Berlusconi's political success is that people feel a deep affinity with him. This argument is hardly questionable per se, in view of the exceptional consensus which the former Italian prime minister enjoyed for about 20 years. The objective of this paper is rather to investigate how this consensus was formed and kept despite the never-ending series of scandals in which Mr Berlusconi has been involved. In other words, we try to improve our understanding of whether the Italian media, specifically the television, allow public opinion to be formed in an objective and impartial way. Not surprisingly, centre-right political commentators argue that television does not exert any particular bias on public opinion. More surprisingly, this view seems to have been shared in the last 20 years by all centre-left coalitions, who never proposed a law to regulate Mr Berlusconi's huge conflict of interest. If the assumption of television's irrelevance were true, one could reasonably expect to find no significant relationship between trust in TV and trust in Mr Berlusconi as prime minister. Contrary to this hypothesis, our empirical analysis shows that trust in television is the strongest predictor of trust in the Italian prime minister in Spring 2011, thus suggesting that Mr Berlusconi's media empire plays a key role in the building of his political consensus.

This result passes all robustness checks and holds in IV estimates. It must be remarked that the cross-sectional design of the research dictates caution in the interpretation of correlations as causal relationships. Moreover, we could not control for a series of phenomena which could potentially influence both the dependent variable and trust in television, such as trust in other information channels (see for example Gil de Zúñiga et al. 2011), interviewees' vote intentions, and active political participation (Fischer 2011), which were not measured in our dataset. Nonetheless, this paper contributes to the literature by carrying out the first econometric investigation into the role of television in steering political consensus, with a special focus on trust towards the former Italian prime minister. To our knowledge, despite its economic relevance this topic is neglected in the literature. We hope our work has a ripple effect in stimulating further research on political representatives' conflicts of interest in the media sector.

The policy implications of the study are so straightforward that may look obvious, at least in most Western democracies. A regulation of conflicts of interest should be a primary objective in the political agenda of every democratic government, independent of its political colour. Democracy has been defined in various ways by philosophers and political scientists. But whatever definition is used, there is no doubt that to qualify as a democracy a regime must allow the selection of the leadership and the formulation of general rules as a result of popular decisions, which are based on a public consensus of citizens. A democracy requires that this consensus must be formed freely, without manipulation by anyone who has the power to control the mass media.

Conflicts of interest are not a problem peculiar to the present Italian system, but one of the unavoidable issues of democratic theory to which all democratic 


\section{WHO TRUSTS BERLUSCONI?}

systems have brought a response. Thus, promoting a set of rules to regulate the conflicts of interest of political representatives is not a partisan demand based on the desire to attack one specific leader. Rather, it is a necessary step to allow democracy to work properly.

\section{BIBLIOGRAPHY}

Antoci, Angelo, Fabio Sabatini and Mauro Sodini (2011a). The Solaria Syndrome: Social Capital in a Hyper-technological Growing Economy, Journal of Economic Behavior \& Organization. Doi:10.1016/j.jebo.2010.12.018.

Antoci, Angelo, Fabio Sabatini and Mauro Sodini (2011b). Bowling Alone but Tweeting Together: the Evolution of Human Interaction in the Social Networking Era. MPRA Paper 34232.

Argyle, Michael (2001). The Psychology of Happiness. London: Routledge.

Baldassarre, Marak, Sarah Rosenfield and Karen Rook (1984). The Types of Social Relations Predicting Elderly Well-being, Research on Aging. 6: 549-559.

Baum, Christopher F., Mark E. Schaffer and Steven Stillman (2007). IVREG28: Stata Module for Extended Instrumental Variables/2SLS and GMM Estimation (v8). Statistical Software Components S4254011, Boston College Department of Economics, revised 30 Jan 2011.

Besley, Timothy J. and Robin Burgess (2002). The Political Economy of Government Responsiveness, Quarterly Journal of Economics. 117: 1415-1451.

Blondel, Jean and Paolo Segatti (eds) (2003). Italian Politics: the Second Berlusconi Government. New York: Berghahn Books.

Brevini, Benedetta (2010) Towards PSB 2.0? Applying the PSB Ethos to Online Media in Europe: a Comparative Study of PSBs' Internet Policies in Spain, Italy and Britain, European Journal of Communication. 25(4): 348-365.

Bruni, Luigini and Luca Stanca (2006). Income Aspirations, Television and Happiness: Evidence from World Value Surveys, Kyklos. 59(2): 209-225.

Bruni, Luigino and Luca Stanca (2008). Watching Alone: Relational Goods, Television and Happiness, Journal of Economic Behavior \& Organization. 65: 506-528.

Caprara, Gian Vittorio, Claudio Barbaranelli and Philip G. Zimbardo (2002). When Parsimony Subdues Distinctiveness: Simplified Public Perceptions of Politicians' Personality, Political Psychology. 23(1): 77-95.

Caprara, Gian Vittorio, Michele Vecchione, C. Barbaranelli and R. Chris Fraley (2007). When Likeness Goes with Liking: The Case of Political Preference, Political Psychology. 28(5): 609-632.

Center for the Study of Democracy (2010). Examining the Links Between Organised Crime and Corruption. Brussels: European Commission.

Connolly, Sara and Shaun P. Hargreaves Heap (2007). Cross Country Differences in Trust in Television and the Governance of Public Broadcasters, Kyklos. 60(1): 3-14.

Corneo, Giacomo (2005). Work and Television, European Journal of Political Economy: 21(1): 99-113.

D'Hombres, Beatrice, Lorenzo Rocco, Marc Suhrcke and Martin McKee (2010). Does Social Capital Determine Health? Evidence from Eight Transition Countries, Health Economics. 19(1): 56-74.

Degli Antoni, Giacomo (2006). Capitale sociale e crescita economica: verifica empirica a livello regionale e provinciale, Rivista Italiana degli Economisti: 11(3): 363-394.

Degli Antoni, Giacomo (2009). Does Satisfaction Matter? A Microeconomic Empirical Analysis of the Effect of Social Relations on Economic Welfare, Journal of Socio-Economics. 38(2): 301-309.

Demir, Melikşah, Metin Özdemir and Lesley A. Weitekamp (2007). Looking to Happy Tomorrows with Friends: Best and Close Friendships as they Predict Happiness, Journal of Happiness Studies. 8(2): 243-271. 


\section{FABIO SABATINI}

Demir, Melikşah and Lesley A. Weitekamp (2007). I am so Happy 'cause Today I Found my Friend: Friendship and Personality as Predictors of Happiness, Journal of Happiness Studies. 8(2): $181-211$.

Diener, Ed and Seligman, Martin E. P. (2002). Very Happy People, Psychological Science. 13(1): $81-84$.

Durlauf, Steven N. and Marchel Fafchamps (2005). Social Capital. In Durlauf, Steven N. and Marchel Fafchamps (eds), Handbook of Economic Growth. Amsterdam: Elsevier - North Holland: 1639_ 1699.

Fine, Ben (2001). Social Capital Versus Social Theory. Political Economy and Social Science at the Turn of the Millenium. London: Routledge.

Fiorillo, Damiano (2008). Le determinanti del capitale sociale in Italia, Rivista Italiana degli Economisti. 13(1): 81-135.

Fiorillo, Damiano and Fabio Sabatini (2011). Quality and Quantity: the Role of Social Interactions in Individual Health. Social Science \& Medicine. DOI: 10.1016/j.socscimed.2011.09.007.

Fischer, Justina A. V. (2011). Living under the 'Right' Government: Does Political Ideology Matter to Trust in Political Institutions? An Analysis for OECD Countries. MPRA paper 33344.

Frey, Bruno S., Christine Benesch and Alois Stutzer (2007). Does Watching TV Make us Happy? Journal of Economic Psychology. 28: 283-313.

Gil de Zúñiga, Homero, Nakwon Jung and Sebastian Valenzuela (2011). Social Media Use for News and Individuals' Social Capital, Civic Engagement and Political Participation. Journal of Computer-Mediated Communication. In press.

Ginsborg, Paul (2005). Silvio Berlusconi. Television, Power and Patrimony. London and New York: Versobooks.

Istat (2008). L'uso dei media e del cellulare in Italia. Roma: Istat.

Lyubomirsky Sonja, Tkach, Dimatteo Chris, M. Robin (2006). What are the Differences between Happiness and Self-esteem? Social Indicators Research. 78: 363-404.

Myers, David G. (2000). The Funds, Friends, and Faith of Happy People. American Psychologist. 55: 56-67.

Roodman, David (2009). Estimating Fully Observed Recursive Mixed-process Models with Cmp. Working Paper 168. Center for Global Development. Washington, DC.

Rosenberg, Morris (1956). Misanthropy and Political Ideology, American Sociological Review. 21: 690-695.

Putnam, Robert D. (1995). Tuning in, Tuning out - the Strange Disappearance of Social Capital in America, Political Science \& Politics. 28(4): 664-683.

Sabatini, Fabio (2007). The Empirics of Social Capital and Economic Development: a Critical Perspective. In Osborne, Michael, Sankey, Kate and Bruce Wilson (eds). Social Capital, Lifelong Learning Regions and the Management of Place: an international perspective. London and New York, Routledge: 76-94.

Sabatini, Fabio (2008). Social Capital and the Quality of Economic Development, Kyklos. 61(3): 466-499.

Sabatini, Fabio (2009a). Social Capital as Social Networks: a New Framework for Measurement and an Empirical Analysis of its Determinants and Consequence, Journal of Socio-Economics. 38(3): 429-442.

Sabatini, Fabio (2009b). Il capitale sociale nelle regioni italiane: un'analisi comparata, Rivista di Politica Economica. 99(2): 167-220.

Uphoff, Norman (1999). Understanding Social Capital: Learning from the Analysis and Experience of Participation. In Dasgupta, Partha and Ismail Serageldin (eds.). Social Capital: A Multifaceted Perspective. Washington, D.C.: The World Bank: 215-249.

Van Praag Bernard M. S. and Ada Ferrer-i-Carbonell (2008). Happiness Quantified. A Satisfaction Calculus Approach. Oxford: Oxford University Press. 


\section{WHO TRUSTS BERLUSCONI?}

Warner, Carolyn M. (2007). The Best System Money Can Buy. Corruption in the European Union. New York: Cornell University Press.

Wooldridge, Jeffrey M. (2002). Econometric Analysis of Cross Section and Panel Data. Cambridge, Massachusetts: The MIT Press.

Yamamura, Eiji (2011). The Role of Social Trust in Reducing Long-term Truancy and Forming Human Capital in Japan, Economics of Education Review. 30(2): 380-389.

\section{APPENDIX}

Table A1

Preferences for Mr Berlusconi's party and the centre-right coalition in the last three ballotings

\begin{tabular}{lcc}
\hline Election & $\begin{array}{c}\text { Mr Berlusconi's party } \\
\text { (People of Freedom) }\end{array}$ & $\begin{array}{c}\text { Centre-right } \\
\text { coalition }\end{array}$ \\
\hline $\begin{array}{lcc}\text { European Parliament election 2009 } \\
\text { (National data in brackets) }\end{array}$ & 26.29 & 43.22 \\
Elections of the Chamber of Deputies 2008. & $(35.26)$ & $(45.46)$ \\
(National data in brackets) & 27.44 & 46.62 \\
Local administration election 2008 & $(37.39)$ & $(46.81)$ \\
\hline
\end{tabular}

Table A2

Description of variables

Trust in the Italian prime minister

Trust in television

Membership in
associations
Number of
associations
Volunteer unpaid work
for associations
Help to strangers
within volunteering
activities
Participation in
associational
meetings
Social trust

Trust in the judicial system

Tolerance towards non EU immigrants
1-10 points respondents' score to the question "Do you think that the prime minister can be trusted?" Responses equal to 6 and above are coded 1 .

1-10 points respondents' score to the question "Do you think that television can be trusted?" Responses above the mean value are coded 1.

Membership in associations; $1=$ the interviewee is member and/or participates in the activities of one or more associations.

Number of associations to which the interviewee participates.

Binary variable $=1$ if the interviewee has done unpaid volunteer work for associations in the last 12 months before the interview.

Binary variable $=1$ if the interviewee has concretely helped strangers in the last 12 months before the interview.

Binary variable $=1$ if the interviewee has joined meetings of voluntary association sin the last 12 months before the interview.

Trust towards strangers, given by the 10 points respondents' score to the question "Generally speaking, do you think that most people can be trusted?"; 1 = values above the mean.

Trust towards the judicial system, given by the 10 points respondents' score to the question "Do you think that the judicial system can be trusted?". 1 = values above the mean.

Tolerance towards non EU immigrants, as given by 1-5 respondents' score to the question: "Would you be willing to have non EU immigrants as neighbours?", 1 meaning "Totally unfavourable", 3 meaning "Indifferent", 5 meaning "Totally favourable". Binary variable $=1$ if interviewee is willing or indifferent to have non EU immigrants as neighbours. 


\section{FABIO SABATINI}

Table A2 (Contd)

Tolerance towards EU immigrants

Tolerance towards drug or alcohol addicts

Age 35-49

Age 50-64

Age 65 and more

Female

Being in a stable relationship

Educational qualification (ordinal)

Precarious worker

Blue-collar worker

Office worker

Teacher

Managerial employee

Member of
professions
Entrepreneur
Farmer
Unemployed
Retired
Homemaker
Area or residence
$\quad$ (urban vs. rural)
Poor

Quality of friendships

Trust in the press
Tolerance towards EU immigrants, as given by 1-5 respondents' score to the question: "Would you be willing to have EU immigrants as neighbours?", 1 meaning "Totally unfavourable", 3 meaning "Indifferent", 5 meaning "Totally favourable". Binary variable = 1 if interviewee is willing or indifferent to have EU immigrants as neighbours.

Tolerance towards non drug and alcohol addicts, as given by 1-5 respondents' score to the question: "Would you be willing to have drug and alcohol addicts as neighbours?", 1 meaning "Totally unfavourable", 3 meaning "Indifferent", 5 meaning "Totally favourable". Binary variable $=1$ if interviewee is willing or indifferent to have towards drug or alcohol addicts as neighbours.

Age of the respondent; $1=$ age between 35 and 49

Age of the respondent; $1=$ age between 50 and 64

Age of the respondent; $1=$ age 65 and more

$1=$ female

$1=$ the respondent is in a stable relationship, including marriage

Ordinal variable assuming the following values; $1=$ no educational qualification; 2 = elementary school $(5$ years $) ; 3=$ junior high school ( 8 years); $4=$ high school (13 years); $5=$ university degree and/or doctorate (18 years and more).

Binary variable $=1$ if the respondent is a precarious worker with a temporary or no contract of employment.

Binary variable $=1$ if the respondent is blue-collar worker with permanent contract of employment.

Binary variable $=1$ if the respondent is office worker with permanent contract of employment.

Binary variable $=1$ if the respondent is teacher with permanent contract of employment.

Binary variable $=1$ if the respondent managerial employee with permanent contract of employment (includes college teachers, magistrates, university researchers).

Binary variable $=1$ if the respondent is member of professions.

Binary variable $=1$ if the respondent is entrepreneur.

Binary variable $=1$ if the respondent is farmer.

Binary variable $=1$ if the respondent is unemployed.

Binary variable $=1$ if the respondent is retired.

Binary variable $=1$ if the respondent is homemaker.

Binary variable $=1$ if the respondent lives in a urban area.

Indicator of economic well-being given by responses to the question: "Is your household's income sufficient to see you through to the end of the month?". Respondents were asked to give a score from 1 to 5 , with 1 meaning "With great difficulty" and 5 meaning "Very easily". Binary variable $=1$ for negative responses (i.e. "With great difficulty" and "With difficulty")

Subjective assessment of satisfaction with relationships with friends; $1=$ values above the mean

1-10 points respondents' score to the question "Do you think that the press can be trusted?" Responses above the mean value are coded 1 . 


\section{WHO TRUSTS BERLUSCONI?}

\section{SUMMARY}

The objective of this paper is to improve our understanding on how the former Italian prime minister formed and kept his exceptional political consensus despite the never-ending series of scandals in which he has been involved. Specifically, we carry out an empirical assessment of the relationship between trust in television and trust towards the prime minister. Many Italian commentators argue that television does not exert any particular bias on public opinion. If the assumption of television's irrelevance were true, one could reasonably expect to find no significant relationship between trust in TV and trust in Mr Berlusconi as prime minister. Contrary to this hypothesis, our empirical analysis shows that trust in television was the strongest predictor of trust in the Italian prime minister in Spring 2011, thus suggesting that Mr Berlusconi's media empire played a key role in the building of his political consensus.

This result is based on probit and ordered logit estimates and is robust to different specifications. However, there are three reasons for which this finding could be interpreted as the fruit of a spurious correlation. First, it is difficult to distinguish the effect of trust in television from that of other phenomena that potentially influence trust in the prime minister. To deal with this problem, we include in the main equation a wide set of individual and household control variables. Second, individual effects, such as individuals' exogenous shocks, may be correlated with trust both towards television and the prime minister, thus creating a common bias. Third, as we explain in the paper, it is reasonable to assume the existence of reverse causality. To deal with the last two problems, we turn to instrumental variables (IV) estimates. When we address endogeneity in IV estimates, trust in television remains the best (most significant and strongest) predictor of trust in the prime minister. By contrast, we find that the dependent variable is significantly and negatively correlated with educational qualification, trust in the judicial system and with a measure of tolerance towards immigrants.

Even if these results pass robustness checks and hold in IV estimates, it must be remarked that the cross-sectional design of the research dictates extreme caution in the interpretation of correlations as causal relationships. Nonetheless, the paper contributes to the literature by carrying out the first econometric investigation into the role of television in individuals' political opinions, with a focus on trust towards the Italian prime minister. The relationship between television and political attitudes and beliefs is an important topic for economics, in view of the unquestionable role that political institutions, particularly the government and the prime minister, play in a country's economic performance. 